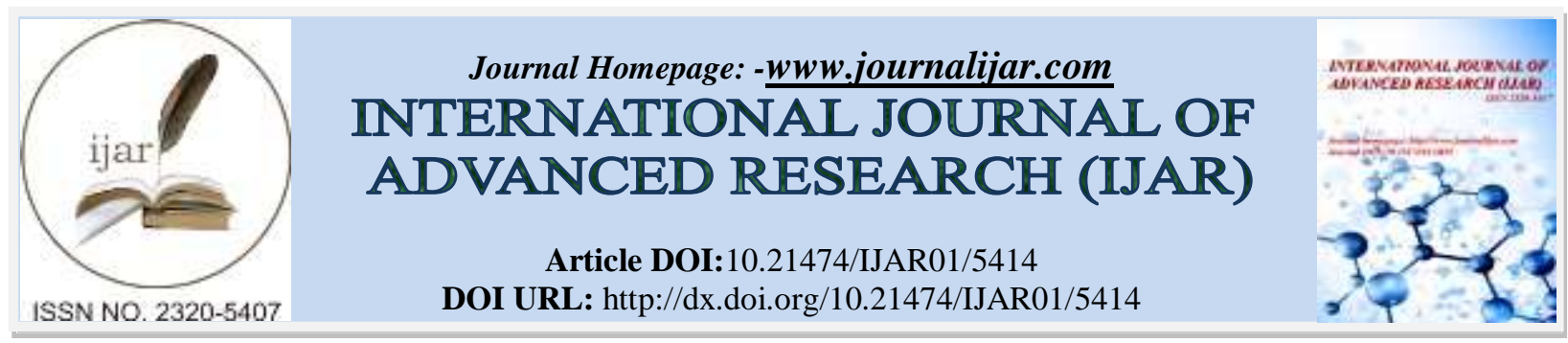

RESEARCH ARTICLE

\title{
INFLUENCE OF PLANT GEOMETRY AND NATURAL FARMING ON PLANT AND RATOON OF SUGARCANE.
}

\section{S. C. Singh ${ }^{1}$, ${ }^{\text {Shriprakash } \operatorname{Yadav}^{1} \text {, Sonia } \operatorname{Yadav}^{1} \text { and B. L. Sharma }}{ }^{2}$.}

1. Scientists - Sugarcane Research Institute, Shahjahanpur (U.P.), India.

2. Director -U.P Council of Sugarcane Research, Shahjahanpur (U.P.), India.

\section{Manuscript Info}

Manuscript History

Final Accepted: 14 August 2017

Published: September 2017

Key words:-

Sugarcane, Geometry, Natural farming,

Economics and Soil health.
Received: 12 July 2017

\begin{abstract}
A field experiment was conducted during 2014 - 16 (Plant cane) and 2016 - 17 (ratoon cane) at the research farm of Sugarcane Research Institute, Shahjahanpur to study the effect of plant geometry and natural farming on yield, quality, soil health and economics. The experiment was laid out in randomized block design with three replications. The soil of experimental field had organic carbon $(0.33 \%)$, phosphorus $(9.20 \mathrm{~kg} / \mathrm{ha})$ and potash $(106.6 \mathrm{~kg} / \mathrm{ha}), \mathrm{pH} 6.90$, bulk density $(1.12$ $\mathrm{g} / \mathrm{cm}^{3}$ ) with soil microbial population of $1.5 \times 10^{7} \mathrm{cfu} / \mathrm{g}$. Experimental crop was planted with variety Co 05011 through one and three budded sett at different geometry as per treatment comprising five treatments. Experimental results exhibited that planting of three budded sett at row spacing of $240 \mathrm{~cm}$ with conventional practices $\left(\mathbf{T}_{\mathbf{1}}\right)$ produced significantly higher plant cane yield (63.97 t/ha) and intercrop yield of lahi $(9.13 \mathrm{q} / \mathrm{ha})$, lentil $(1.82 \mathrm{q} / \mathrm{ha})$ and moong $(2.60 \mathrm{q} / \mathrm{ha})$ followed by planting of one budded sett at row spacing of $240 \mathrm{~cm}$ and bud to bud $60 \mathrm{~cm}$ spacing with natural farming $\left(\mathbf{T}_{2}\right)$ with plant cane yield of 54.13 $\mathrm{t} / \mathrm{ha}$ and intercrop yield of lahi ( $8.45 \mathrm{q} / \mathrm{ha})$, lentil $(1.74 \mathrm{q} / \mathrm{ha})$ and moong (2.23 q/ha). However, significantly higher ratoon cane yield $(69.89$ t/ha) was recorded in planting of one budded sett at row spacing of $240 \mathrm{~cm}$ and bud to bud $60 \mathrm{~cm}$ spacing with natural farming $\left(T_{2}\right)$ ) followed by planting of three budded sett at row spacing of $240 \mathrm{~cm}$ with conventional practices $\left(\mathbf{T}_{\mathbf{1}}\right)$ with ratoon cane yield of $51.41 \mathrm{t} / \mathrm{ha}$. Maximum B:C ratio (2.5) in plant cane was found in $\mathrm{T}_{1}$ treatment followed by $\mathrm{T}_{2}$ while, in ratoon cane maximum $\mathrm{B}: \mathrm{C}$ ratio (2.89) was obtained in $\mathrm{T}_{2}$ treatment followed by $\mathrm{T}_{3}$ treatment with $\mathrm{B}: \mathrm{C}$ ratio of 2.68. Organic matter, available NPK and microbial population were found to be better in natural farming treatments than that of conventional treatment.
\end{abstract}

Copy Right, IJAR, 2017,. All rights reserved.

\section{Introduction:-}

After long time of the introduction of the chemical farming and indiscriminate use of chemical products (fertilizers and pesticides) adversely affected quality of natural resources (soil and water) as well as the health of living beings. This imposes problem to the environment and adversely affects the soil chemical as well as microbial activities and 
ultimately human health. Farmers are also struggling to get success in agriculture and facing problems due to increase in production cost and more infestation of insect-pests and diseases. It indicates that the existing technology will not be good for a long term sustainability which contaminates foods, causing food borne illness and adversely affecting the eco-system. However, there is a great opportunity for economic sustainability afforded by enterprise diversification and natural farming to reap safe produce along with safe environment. Natural farming is unique method of crop production based on natural resources like cattle dung, urine and rural products which bring sustainability to agriculture with eco-friendly manner. Therefore, it becomes imperative for the researchers to develop an alternative and viable technology to substitute the chemical farming. Considering these points in view an experiment was carried out to study the Influence of plant geometry and natural farming on yield, quality, soil health and economics under sugarcane cropping system.

\section{Materials AndMethod:-}

A field experiment was conducted during 2014 - 16 (Plant cane) and 2016 - 17 (Ratoon cane) at the research farm of Sugarcane Research Institute, Shahjahanpur. Experiments were carried out in randomized block design with three replications. The soil of experimental field had organic carbon (0.33\%), available nitrogen (193.06 kg/ha), phosphorus $(9.20 \mathrm{~kg} / \mathrm{ha})$ and potash $(106.6 \mathrm{~kg} / \mathrm{ha}), \mathrm{pH} 6.90$, bulk density $\left(1.12 \mathrm{~g} / \mathrm{cm}^{3}\right)$ with soil microbial population of $1.5 \times 10^{7} \mathrm{cfu} / \mathrm{g}$. Experimental crop was planted with variety Co 05011 through one and three budded sett at different plant geometry as per treatment on 04.10.2014 and harvested on 10.02.2016. Ratoon crop was started on 10.02.2016 and harvested on 01.02.2017. In natural farming treatments plant and ratoon cane were raised through natural based resources and it comprised of sett treatment with Beejamrut (Cow dung, urine and lime), nutrition with Ghanjeevamrut (Cow dung, pulse flour and gur), Jeevamrut (Cow dung, urine, pulse flour and gur) and plant protection with biopesticides (fermented curd water, neem oil, cow urine and neem leaves) alongwith trash mulching and intercropping of lahi, lentil, and moong in alternate rows. The treatment details were as follows:

\section{Treatments:-}

$\mathbf{T}_{\mathbf{1}^{-}}$Planting of three budded sett at the row distance of $240 \mathrm{~cm}$ with conventional practices.

$\mathbf{T}_{2^{-}}$Panting one budded sett at the row distance of $240 \mathrm{~cm}$ and bud to bud $60 \mathrm{~cm}$ with natural farming.

$\mathbf{T}_{\mathbf{3}^{-}}$- Planting one budded sett at the row distance of $240 \mathrm{~cm}$ and bud to bud $120 \mathrm{~cm}$ with natural farming.

$\mathbf{T}_{4}$ - Planting one budded sett at the row distance of $240 \mathrm{~cm}$ and bud to bud $180 \mathrm{~cm}$ with natural farming.

$\mathbf{T}_{\mathbf{5}}$ - Planting one budded sett at the row distance of $240 \mathrm{~cm}$ and bud to bud $240 \mathrm{~cm}$ with natural farming.

Table 1a:- Effect of treatments on germination, shoots, millable canes, cane yield, CCS \%, inter crop yield and B:Crati (Plant cane)

\begin{tabular}{|c|c|c|c|c|c|c|c|c|c|c|}
\hline \multirow{2}{*}{\multicolumn{2}{|c|}{ Treatments }} & \multirow{3}{*}{$\begin{array}{l}\begin{array}{l}\text { Germination } \\
(\%)\end{array} \\
37.68\end{array}$} & \multirow{3}{*}{\begin{tabular}{|l}
$\begin{array}{l}\text { Shoots } \\
\text { (000/ha) }\end{array}$ \\
62.94 \\
\end{tabular}} & \multirow{3}{*}{$\begin{array}{l}\begin{array}{l}\text { NMC } \\
\text { (000/ha) }\end{array} \\
58.76\end{array}$} & \multirow{3}{*}{$\begin{array}{l}\begin{array}{l}\text { Cane } \\
\text { yield } \\
\text { (t/ha) }\end{array} \\
63.97 \\
\end{array}$} & \multirow{3}{*}{$\begin{array}{l}\begin{array}{l}\text { CCS } \\
(\%)\end{array} \\
11.72 \\
\end{array}$} & \multicolumn{3}{|c|}{$\begin{array}{l}\text { Inter crop yield } \\
\text { (q/ha) }\end{array}$} & \multirow[t]{2}{*}{$\begin{array}{l}\text { B:C } \\
\text { Ratio }\end{array}$} \\
\hline & & & & & & & Lahi & Lentil & Moong & \\
\hline $\mathrm{T}_{1}$ & $\begin{array}{l}\text { Planting of three } \\
\text { budded sett at the } \\
\text { row distance of } 240 \\
\text { cm with } \\
\text { conventional } \\
\text { practices. }\end{array}$ & & & & & & 9.13 & 1.82 & 2.60 & 2.5 \\
\hline $\mathrm{T}_{2}$ & $\begin{array}{l}\text { Panting of one } \\
\text { budded sett at the } \\
\text { row distance of } 240 \\
\mathrm{~cm} \text { and bud to bud } \\
60 \mathrm{~cm} \text { with natural } \\
\text { farming. }\end{array}$ & 85.76 & 61.42 & 56.40 & 54.13 & 11.86 & 8.45 & 1.74 & 2.23 & 2.4 \\
\hline $\mathrm{T}_{3}$ & $\begin{array}{l}\text { Planting of one } \\
\text { budded sett at the } \\
\text { row distance of } 240 \\
\mathrm{~cm} \text { and bud to bud } \\
120 \mathrm{~cm} \text { with natural } \\
\text { farming. }\end{array}$ & 85.42 & 44.75 & 41.74 & 41.74 & 11.65 & 8.33 & 1.63 & 2.31 & 2.2 \\
\hline
\end{tabular}




\begin{tabular}{|l|l|l|l|l|l|l|l|l|l|l|}
\hline $\mathrm{T}_{4}$ & $\begin{array}{l}\text { Planting of one } \\
\text { budded sett at the } \\
\text { row distance of 240 } \\
\text { cm and bud to bud } \\
180 \text { cm with natural } \\
\text { farming. }\end{array}$ & 84.38 & 30.45 & 26.74 & 26.74 & 11.61 & 8.56 & 1.55 & 2.36 & 1.7 \\
\hline $\mathrm{T}_{5}$ & $\begin{array}{l}\text { Planting of one } \\
\text { budded sett at the } \\
\text { row distance of 240 } \\
\text { cm and bud to bud } \\
\text { 240 cm with natural } \\
\text { farming. }\end{array}$ & 86.12 & 22.91 & 23.05 & 23.05 & 11.77 & 8.85 & 1.75 & 2.44 & 1.6 \\
\hline SE \pm & $\mathbf{2 . 8 8}$ & $\mathbf{6 . 2 8}$ & $\mathbf{1 . 4 4}$ & $\mathbf{2 . 1 2}$ & $\mathbf{2 . 0 9}$ & $\mathbf{N S}$ & - & - & - & \\
\hline CD 5\% &
\end{tabular}

Table 1b:-Effect of treatments on soil organic matter, nutrient status, bulk density and microbial population at harvest (Plant cane)

\begin{tabular}{|c|c|c|c|c|c|c|c|}
\hline \multicolumn{2}{|c|}{ Treatments } & \multirow{2}{*}{$\begin{array}{l}\begin{array}{l}\text { OC } \\
(\%)\end{array} \\
0.44\end{array}$} & \multicolumn{3}{|c|}{ Available } & \multirow{2}{*}{$\begin{array}{l}\begin{array}{l}\text { Bulk } \\
\text { density } \\
\left(\mathrm{g} / \mathrm{cm}^{3}\right)\end{array} \\
1.26\end{array}$} & \multirow{2}{*}{$\begin{array}{l}\begin{array}{l}\text { Soil } \\
\text { microbial } \\
\text { population } \\
\text { (cfu/g) }\end{array} \\
1.5 \times 10^{7}\end{array}$} \\
\hline$T_{1}$ & $\begin{array}{l}\text { Planting of three budded sett at } \\
\text { the row distance of } 240 \mathrm{~cm} \text { with } \\
\text { conventional practices. }\end{array}$ & & 227.43 & 11.07 & 167.23 & & \\
\hline $\mathbf{T}_{2}$ & $\begin{array}{l}\text { Panting of one budded sett at } \\
\text { the row distance of } 240 \mathrm{~cm} \text { and } \\
\text { bud to bud } 60 \mathrm{~cm} \text { with natural } \\
\text { farming. }\end{array}$ & 0.48 & 239.36 & 20.80 & 172.50 & 1.15 & $2.2 \times 10^{7}$ \\
\hline $\mathbf{T}_{3}$ & $\begin{array}{l}\text { Planting of one budded sett at } \\
\text { the row distance of } 240 \mathrm{~cm} \text { and } \\
\text { bud to bud } 120 \mathrm{~cm} \text { with natural } \\
\text { farming. }\end{array}$ & 0.42 & 221.46 & 12.39 & 164.35 & 1.19 & $1.9 \times 10^{7}$ \\
\hline $\mathbf{T}_{4}$ & $\begin{array}{l}\text { Planting of one budded sett at } \\
\text { the row distance of } 240 \mathrm{~cm} \text { and } \\
\text { bud to bud } 180 \mathrm{~cm} \text { with natural } \\
\text { farming. }\end{array}$ & 0.41 & 218.48 & 11.02 & 161.80 & 1.16 & $1.8 \times 10^{7}$ \\
\hline$T_{5}$ & $\begin{array}{l}\text { Planting of one budded sett at } \\
\text { the row distance of } 240 \mathrm{~cm} \text { and } \\
\text { bud to bud } 240 \mathrm{~cm} \text { with natural } \\
\text { farming. }\end{array}$ & 0.38 & 208.38 & 10.92 & 159.39 & 1.14 & $1.6 \times 10^{7}$ \\
\hline
\end{tabular}

Table 2a:-Effect of treatments on stubbles, mother shoots, shoots, millable canes, cane yield, CCS \% and B:C ratio (Ratoon cane)

\begin{tabular}{|l|l|l|l|l|l|l|l|l|}
\hline \multicolumn{2}{|l|}{ Treatments } & $\begin{array}{l}\text { Stubbles/ } \\
\text { ha }\end{array}$ & $\begin{array}{l}\text { M. } \\
\text { shoots } \\
(\mathbf{0 0 0 / h a})\end{array}$ & $\begin{array}{l}\text { Shoots } \\
(\mathbf{0 0 0 / h a})\end{array}$ & $\begin{array}{l}\text { Millable } \\
\text { canes } \\
(\mathbf{0 0 0 / h a})\end{array}$ & $\begin{array}{l}\text { Cane } \\
\text { yield } \\
\text { (t/ha) }\end{array}$ & $\begin{array}{l}\text { CCS } \\
(\%)\end{array}$ & $\begin{array}{l}\text { B:C } \\
\text { Ratio }\end{array}$ \\
\hline $\mathbf{T}_{\mathbf{1}}$ & $\begin{array}{l}\text { Planting of three budded sett } \\
\text { at the row distance of 240 } \\
\text { cm with conventional } \\
\text { practices. }\end{array}$ & 7137 & 33.88 & 81.33 & 50.76 & 51.41 & 11.60 & 1.71 \\
\hline $\mathbf{T}_{\mathbf{2}}$ & $\begin{array}{l}\text { Panting of one budded sett } \\
\text { at the row distance of 240 } \\
\text { cm and bud to bud 60 cm } \\
\text { with natural farming. }\end{array}$ & 6221 & 34.55 & 99.56 & 71.48 & 69.89 & 11.72 & 2.89 \\
\hline
\end{tabular}




\begin{tabular}{|l|l|l|l|l|l|l|l|l|}
\hline $\mathbf{T}_{\mathbf{3}}$ & $\begin{array}{l}\text { Planting of one budded sett } \\
\text { at the row distance of 240 } \\
\text { cm and bud to bud } 120 \mathrm{~cm} \\
\text { with natural farming. }\end{array}$ & 3400 & 17.87 & 81.21 & 61.54 & 61.56 & 11.67 & 2.68 \\
\hline $\mathbf{T}_{\mathbf{4}}$ & $\begin{array}{l}\text { Planting of one budded sett } \\
\text { at the row distance of } 240 \\
\text { cm and bud to bud } 180 \mathrm{~cm} \\
\text { with natural farming. }\end{array}$ & 2315 & 12.39 & 64.40 & 49.45 & 53.17 & 11.53 & 2.36 \\
\hline $\mathbf{T}_{\mathbf{5}}$ & $\begin{array}{l}\text { Planting of one budded sett } \\
\text { at the row distance of 240 } \\
\text { cm and bud to bud 240 cm } \\
\text { with natural farming. }\end{array}$ & 1718 & 9.93 & 51.72 & 44.46 & 48.01 & 11.31 & 2.14 \\
\hline $\mathbf{S E} \pm$ & $\mathbf{3 7 9 . 1 6}$ & $\mathbf{1 . 6 7}$ & $\mathbf{3 . 4 3}$ & $\mathbf{3 . 8 3}$ & $\mathbf{0 . 2 1}$ & $\mathbf{0 . 1 5}$ & - \\
\hline $\mathbf{C D}$ (5\%) & $\mathbf{8 2 6 . 2 0}$ & $\mathbf{3 . 6 4}$ & $\mathbf{7 . 5 1}$ & $\mathbf{8 . 3 4}$ & $\mathbf{0 . 4 6}$ & $\mathbf{N S}$ & - \\
\hline
\end{tabular}

Table 2b:- Effect of treatments on soil organic matter, nutrient status, bulk density and microbial population at harvest (Ratoon cane)

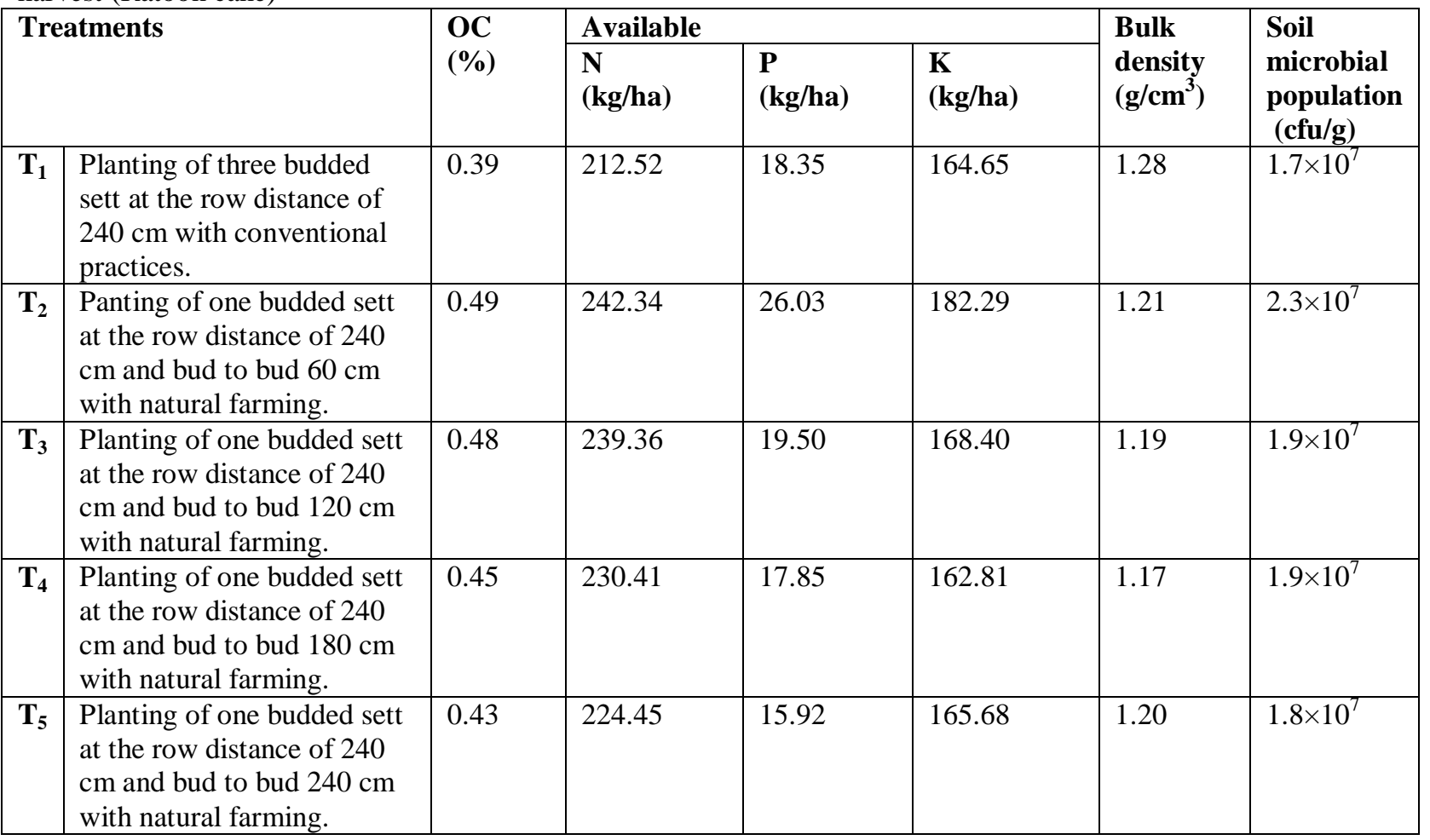

\section{Results AndDisscussion:-}

Experimental results revealed that significantly higher germination percent $(84.42 \%-86.12 \%)$ were recorded in planting of one budded setts with natural farming practices as compared to planting of three budded setts in conventional practices with germination percent of $37.68 \%$ in plant cane (Table1a). However, planting of three budded setts at row spacing of $240 \mathrm{~cm}$ with conventional practices $\left(\mathrm{T}_{1}\right)$ produced significantly higher number of shoots $(62,940 / \mathrm{ha})$, millable canes $(58,760 / \mathrm{ha})$, cane yield $(63.97 \mathrm{t} / \mathrm{ha})$ and intercrop yield of lahi $(9.13 \mathrm{q} / \mathrm{ha})$, lentil $(1.82 \mathrm{q} / \mathrm{ha})$ and moong $(2.60 \mathrm{q} / \mathrm{ha})$ followed by planting of one budded setts at row spacing of $240 \mathrm{~cm}$ and bud to bud $60 \mathrm{~cm}$ spacing with natural farming $\left(\mathrm{T}_{2}\right)$ with number of shoots $(61,420 / \mathrm{ha})$, millable canes $(56,400 / \mathrm{ha})$, cane yield (54.13 t/ha) and intercrop yield of lahi ( $8.45 \mathrm{q} / \mathrm{ha})$, lentil $(1.74 \mathrm{q} / \mathrm{ha})$ and moong $(2.23 \mathrm{q} / \mathrm{ha})$. Since, planting of three budded sett required higher seed rate in conventional practices and due to increase in seed quantity in three budded sett planting with conventional practices plant cane yield was increased significantly over one budded sett planting with natural farming practices. Similar results were also reported by Singh et.al. 1996. Trash mulching and intercropping of lahi, lentil and moong with plant cane were found to be effective in improving soil health and it also 
provided favourableeffect on cane yield due to higher nutrient availability (Table 1b). Maximum B:C ratio (2.5) in plant cane was obtained in $\mathrm{T}_{1}$ treatment followed by $\mathrm{T}_{2}$ treatment.

In ratoon cane (Table 2a, b) significantly higher shoots (99,560/ha), millable canes (71,480/ha) and cane yield $(69.89 \mathrm{t} / \mathrm{ha})$ were recorded in ratoon cane through planting of one budded sett at row spacing of $240 \mathrm{~cm}$ and bud to bud $60 \mathrm{~cm}$ spacing with natural farming $\left(\mathrm{T}_{2}\right)$ followed by planting of three budded setts at row spacing of $240 \mathrm{~cm}$ with conventional practices $\left(T_{1}\right)$ with shoot population $(81,330 / \mathrm{ha})$, millable canes $(50,760 / \mathrm{ha})$ and cane yield $(51.41$ t/ha). Trash mulching in alternate rows increased activity of earthworm and also saved irrigation water resulting in economizing water requirement of crop due to increase in water percolation and less water evaporation. These results corroborate with the finding of Yadavet.al. 1986. Maximum B:C ratio (2.89) was also found in $\mathrm{T}_{2}$ treatment followed by $\mathrm{T}_{3}$ treatment with $\mathrm{B}: \mathrm{C}$ ratio of 2.68. Organic matter, available NPK and microbial populations were observed better in natural farming treatments than that of conventional treatment causing beneficial effect on ratooncane yield. Jadhavet.al. 1992 also reported 30\% economy in irrigation water and increased organic matter in soil through trash mulching.

\section{References:-}

1. Jadhav, S.B.; Sankpal, V.Y. and Vaidya, B.R. (1992).Water management in sugarcane under optimum water availability conditions. $3^{\text {rd }}$ State level Sugarcane Research and Development workshop held at Bhopal on 10-11 August.

2. Singh. S.K.P.; Singh, S.S.; Sinha, U.P. and Singh, A.K. (1996). Effect of spacing, seed rate and nitrogen on growth, yield and quality of sugarcane. Indian Journal of Agronomy, 41 (1): 119-121.

3. Yadav, R.L.; Prasad, S.R. and Singh, K. (1986). Effect of potassium and trash mulch on yield and quality of sugarcane under limited water supply. Journal of Potassium Research 2 (4): 136-139. 